Research Journal of Applied Sciences 7 (3): 165-176, 2012

ISSN: $1815-932 \mathrm{X}$

(C) Medwell Journals, 2012

\title{
Students' Perception Towards Malay Provisions in the Federal Constitution in the Context of Ethnic Relationship in Malaysia
}

\author{
Nazri Muslim, Mohd Arip Kasmo, Abdul Latif Samian, Zulkifli Mohamad and Zaharah Hassan \\ Centre for General Studies, Universiti Kebangsaan Malaysia, Kebangsan, Malaysia
}

\begin{abstract}
This research aims to investigate the level of knowledge, understanding, acceptance and perception among the students of Public Higher Education Institutions towards the Malays in the Federal Constitution within the context of ethnic relationship in Malaysia. This research involved 800 respondents selected from four Public Higher Education Institutions. Data for this research was obtained from questionnaires which were analyzed using SPSS program. To serve that purpose, descriptive statistics such as frequency, percentage, min, cross-tabulation statistics and correlation coefficient were employed to explain respondents' background and to evaluate the level of knowledge, understanding and acceptance as well as the students' perception towards the Malays in the constitution. Research findings show that the level of knowledge, understanding and acceptance of the students towards the Malays in the constitution is generally high. The same goes to the students' perception towards the Malays in the Federal Constitution in which they accept the fact that the position of the Malays is better than the non-Malays, the privileges enjoyed by the Malays have improved their standard of living and the use of quotas in government policies needs to be maintained. This is in line with the statement that the students are still aware and sensitive and the government should consider the privileges of the Malays in whatever policies they wanted to implement. However, students have started to accept that as nation of plural society, equal treatment should be given to all races and the use of quotas in government policies should be expanded to other races. They also started to accept that the poor and eligible non-Malays should also be given aids. Next, few recommendations are presented concerning issues that arises which are related to the position of the Malays in the constitution.
\end{abstract}

Key words: Malay provisions, ethnic, Federal Constitution, perception, Malaysia

\section{INTRODUCTION}

Malaysian from various ethnics is very committed towards strengthening the spirit of unity and integration among ethnics and regions. This is important to guarantee the viability of Malaysia as a multi-ethnic county and with regions that are separated apart between the states. From Table 1, it is clear that there are three large ethnics in Malaysia namely the Bumiputera, Chinese and Indian each consisting of $65.9,25.3$ and $7.5 \%$ from the total population of Malaysia in the year 2005. This statistics have revealed that there exist pluralism of society in Malaysia which are divided into three large ethnics namely the Bumiputera that consists of the Malays and the native people of Sabah and Sarawak, Chinese Indian and other ethnics. This pluralism shows that issues pertaining language, religion, the privileges of the Malays and the position of Malay rulers are important factors to establish close ethnic relationship among Malaysians. According to Ratnam (1969) these issues will determine the condition of ethnic relationship in the future by
Table 1: Composition of Malaysian population, 2000-2010 (millions of people)

Total population (million)

Years Bumiputera Chinese Indian Other Ethnics Total population

\begin{tabular}{lllllr}
\hline 2000 & 14.56 & 5.58 & 1.63 & 0.27 & 22.04
\end{tabular}

$\begin{array}{lllll}66.10 & 25.30 & 7.40 & 1.20 & 100.00\end{array}$

$\begin{array}{lrrrrr}2005 & 16.06 & 6.15 & 1.83 & 0.32 & 24.36\end{array}$

$\begin{array}{lllll}65.90 & 25.30 & 7.50 & 1.30 & 100.00\end{array}$

$\begin{array}{llllll}2010 & 17.95 & 6.52 & 1.97 & 0.35 & 26.79\end{array}$

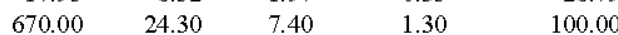

observing how questions on the privileges of the Malays, religion and language are addressed. Therefore, discussion on the institution of Malay rulers, position of Islam, Malay language and Malay privileges have a very close relationship between one another in which one element should not be put aside as it affects other traditional elements. The retention of one element also means retention of other elements, like the bamboo grove and the riverbank (Bari, 2001).

Problem statement: Issues pertaining ethnic relationship in Malaysia have changed a lot in the past five decades.

Corresponding Author: Nazri Muslim, Centre for General Studies, Universiti Kebangsaan Malaysia, Kebangsan, Malaysia 
According to Chandra, controversy among the races in Malaysia can be divided into a few phases. On the 50 's, citizenship and social contract dominated racial relationship followed by the language issues on the 60's prior to the implementation of New Economic Policy (NEP) whilst quotas and urbanization shaped the ethnic relationship during the 70 's and 80 's. On the 90 's and during the millennium, religion-related issues influenced ethnic relationship very strongly in this country. He added that if comparisons are made between issues in racial relationship in Malaysia for the past five decades, the religion issues which came to emergence of late posed a very critical impact. This opinion was supported by Ali (2008) who view the sentiment of ethnic relation in the present time is at a high level which could cause conflict and bloodshed. For example in Malaysia there are 21 racial conflict cases between 1945 to Mei in 1969.

Based on the statistics and monitoring by the Department of National Unity and Integration there were 327 reported cases on social conflicts from 1996-2002. From Table 2, 81 cases related to racial brawl which were the highest followed by 76 political cases, 65 religious conflict and et cetera. Most of racial brawl cases involved school students which were categorized as discipline problems. However, if prevention and monitoring measures are not practiced, it will give serious impacts in the future.

Referring to the question of social contract, the agreements which was not recorded were accepted by the Bumiputera and immigrants in which they are willing to accept the special position of the Malays and other elements for the willingness of the Bumiputera to accept them as a citizen who are entitled the basic rights such as the right to vote and others in return. However, a question arises that is how far this agreement would be accepted by today's younger generation.

This is because at the early stage, tradition and the charisma of the leader were considered as a strong foundation to establish the validity of laws but today's modern community needs a law that is based on rationale, parallel with the changes that have taken place in the country. Besides that the Five Year National Unity and Integration Action Plan (2005-2010) states that issues such as challenging social contract, religious and language friction were frequently brought up and could evoke prolonged conflicts if it is not properly addressed in the context of ethnic relationship in Malaysia. Similarly, the same happen to the perception of some non-Malay communities who considered this social contract as something related to nationality which were given to them when they were immigrants. This is the
Table 2: Reported social conflict from years 1996-2002

\begin{tabular}{lrrrrrrrr}
\hline Conflict type/y ear & 1996 & 1997 & 1998 & 1999 & 2000 & 2001 & 2002 & Total \\
Religion & 7 & 2 & 25 & 11 & 8 & 9 & 3 & 65 \\
Racial & & & & & & & & \\
Brawl & 12 & 4 & 10 & 5 & 8 & 28 & 14 & 81 \\
Civil disorder & 0 & 0 & 4 & 2 & 2 & 1 & 1 & 10 \\
Assassination & 0 & 1 & 0 & 0 & 0 & 0 & 0 & 1 \\
Security & 6 & 0 & 1 & 7 & 6 & 17 & 1 & 38 \\
Racial & 2 & 2 & 1 & 1 & 1 & 0 & 0 & 7 \\
Economics & 0 & 0 & 4 & 0 & 1 & 2 & 1 & 8 \\
Neighborhood & 3 & 3 & 0 & 0 & 0 & 3 & 0 & 9 \\
Illegal settlement & 0 & 0 & 0 & 0 & 0 & 0 & 3 & 3 \\
Others & 0 & 0 & 0 & 0 & 0 & 0 & 1 & 1 \\
Total & 33 & 13 & 67 & 65 & 34 & 75 & 40 & 327 \\
\hline
\end{tabular}

Cited from Hassan (2005), solving conflicts in a multicultural society: the case of Kampung Medan. In Muhammad Kamarul Kabilan dan Zaharah Hassan. Reading on Ethnic Relations in a Multicultural Society. Serdang: Publisher UPM

reason why the non-Malay generation now a days considers that it is something of the past. They could not see why it still needs to be brought up as for them citizenship is something that is given automatically. They are of the opinion that this compromise is tied to a particular time and no longer relevant. The Malays assume that the provision as something sacred whereas some of them argues whether that provision relevant and tied to this particular day.

This becomes more apparent as the attitude of students who do not understand the traditional elements which have been the principal element of unity in Malaysia. Clearly there is a tendency in the younger generation today who begin to question the social contract that has been the principal elements of unity and understanding between ethnics. This group has started to question the special position of the Malays, the role of Malay language and the position of Islam as the official religion of the country. This explanation shows that there emerge a perception that the younger non-Malay generation does not agree with the social contract whilst the younger Malay generation agrees with it, this perception has proven to be wrong nevertheless. Next, the position and implementation of traditional elements in Federal Constitution has never been free from criticism and arguments because non-Malay ethnics feel that the traditional elements have made the current system undemocratic.

Questions and polemics on traditional elements arise and rose frequently. According to Jalil (2007), opposition regarding the provision for the Malays is a tidal discussion. The equality concept pioneered under the slogan of that Malaysian Malaysia was aimed towards elimination of discrimination and unjust treatment that resulted from the employment of Article 153 yet the Malays were very unease feeling that their future was at stake and viewing the slogan as an attempt to question and weaken their position which led to the separation of 
Singapore from Malaysia in 1965 (Abas, 1985). The process that was smoothly executed was the citizenship process according to jus soli principles whilst the conditions which said Malay language as the National Language and the position of the Malays were still challenged and undermined from time to time whereas this issue has already agreed by the non-Malays and applied in the constitution which is the main law for all Malaysians. Critics and oppositions on this matter resurfaced during the General Election of 1969 in which the position of the Malay Rulers Islam, language and the special position of the Malays was challenged by nonMalays (Bari, 2000). Critics and opposition on this matter during the General Election of 1969 caused racial brawl which was referred as the 13 Mei, 1969 incident. As a result, a state of emergency was announced, the Parliament was suspended for 2 years and amendments were made to the constitution which limits freedom of speech and Sedition Act 1948 was revised.

Next, the dispute on the special position of the was raised back when recommendation from Vice Chairman of the Second National Economic Consultative Council (MAPEN II) that requested the government to abolish the provision enjoyed by the Malays under the community restructuring policy if the government wanted to see the Malays advance and self-sustained. This recommendation clearly indicated that the special position of the Malays is continuously being brought up. The particular issue was raised once again when Malaysian Chinese Organization Election Appeals Committee or SUQUI demanded for the traditional elements to be removed and this has caused an anger from various Malay organizations who are in the opinion that the special position of the Malay which was guaranteed by the constitution are not to be argued by SUQUI. The Prime Minister of Malaysia at that time, Dato' Seri Dr. Mahathir Mohamed told Dewan Rakyat that the Malaysian constitution and social contract which is the basis for a country of various ethnics would need to be put aside should all 83 demands from SUQUI are accepted by the government. Instead if all the demands which fall under 17 titles were accepted, Malaysia will no longer peaceful and would be impossible to advance.

This shows that issues involving social contracts or the traditional elements in the constitution especially provisions related to Islam and special position of the Malays would always be a polemic, conflict and controversy in the Malaysian communities since the formulation of the constitution up to this present day. This is true especially when the general election is just around the comer. Ongoing polemics on this issue show how important it is for the traditional elements to be understood and practised by today's younger generations as a social contract.

Polemics on this issue shows that the level of knowledge and understanding of the Malaysian is still low and scarcely practiced, unlike when the agreement on social contract was achieved during the formulation of the Federal Constitution of Malaya. The low level of awareness and understanding on these traditional elements is in accordance to the opinion of Tun Dr. Mahathir Mohamed who wanted the understanding of social contract among the races which had existed way before the independence to be improved. According to him that particular action is necessary to prevent racial friction especially when there are racial issues arise and which are exaggerated.

This statement is supported by Tun Abdullah Ahmad Badawi who later stressed that the failure to implement the social contract among the people is the root of the problems for conflicts in some countries in the world. The same opinion was expressed by Raja Dr. Nazrin Shah on his concerns over the tendency of people in this country to lose sense of tolerance causing separation between ethnic and religious communities in which there are groups from the communities who felt unease with the special treatment whereas other groups view that the special treatment should not be disputed. $\mathrm{He}$ also recommended that the younger generation should try to understand that The Federal Constitution guarantees the rights of all Malaysian thus contributing towards continuing the success in nation formation and efforts to preserve good ethnic relations. This is in line with the command of Yang di Pertuan Agong when officiating the first meeting for second term of the Twelve Parliament Dewan Rakyat, stressed that the history of independence and Federal Constitution needs to be explained to the younger generations so that the better understand the basis of the formation of the nation.

Does this problem reveal that the level of knowledge and understanding as well as its appreciation towards the agreed social contracts during the formation of the constitution among the younger generations is decreasing? Awang also in the opinion that there are still no research being conducted on the question of does today's community, especially the younger generation understand issues pertaining social contracts or the more basic question of does the community understand the content of that social contracts. It is obvious now that from the above discussions, it reveals that there always exists an attempt, from time to time to challenge this social contract including the special position of the Malays. This question has been a never ending issue to be discussed (Bakar, 2009). 
Previous research: Research on the Federal Constitution can be divided into two. Firstly, those adopting historical or political approaches as what being conducted by Ratnam (1969), Means (1991), Von Vorys (1975) and Khoon (1988). Ratnam (1969) and Von Vorys (1975) evaluate the development and expansion of the Malay politics whilst Khoon (1988) investigates development of political consciousness among the Chinese. A research by Means (1991) focuses on few important aspects in the constitution based on the Reid Commission Report, memorandum from organizations and individuals and newspaper reports. Secondly, adopting legislation approach as what being done by Hickling (1960), Hashim (1987), Sheriden and Groves (1979), Hashim et al. (1983) and Bari (2005). However, the discussions from the perspective of ethnic relation are still lacking and much focused on the problems of nation governance.

Research on the special position of the Malays has been touched by few researchers. Among them is a research by Ratnam (1969) which revolves on the acceptance of the Malays and non-Malays towards the special position of the Malays. He is in the opinion that the Malays agree on this matter in improving their standard of living compared to other ethnic. While the views of non-Malays are divided into two, namely a moderate willing to accept the idea that the Malays should be given privileges until there is a term that they can compete without any help. Secondly, those who tend to reject the whole idea of privilege as opposed to democratic policies (Ratnam, 1969).

Hashim (1987) assumes that the 153 Article was not intended to withstand the progress of the non-Malays but it was made so in order to ensure progress of the Bumiputera and they cannot be blamed since they lag behind in term of education, social and economic. The leaders of the Bumiputera have agreed to this provision in return to a loose conditions for citizenship in which enabling them to become citizens only with a stroke of a pen. His discussion focused on the debate why this matter is accepted in the constitution.

Sani (1973) agrees with the opinion given by the Reid Commission on the special position of the Malays which is the continuation of earlier treaties made between the Malay States and British. Abas (1985) explains that the special position of Malays includes employment in the civil service, award of scholarship and aids or other educational facilities and permits and licenses required for business and trade. Included in this special position are the articles 89 and 90 on Malay reserve land and the admission of Malays into The Royal Malay Regiment by article 8 (5). He further added that the special position is not absolute yet balanced with valid rights of other races.
This matter was also touched by Milne and dan Mauzy (1992) who explain that it is a haggling between the Malays and non-Malays and the period for the implementation of this special position of the Malays.

This situation illustrates that an ambiguous shortterm fairness between the various races claim was attained. Milne and Mauzy view shows that Article 153 was agreed upon when drafting the constitution and is difficult to determine its acceptance by the non-Malays in the long term. However, Milne and Mauzy view that says that it is a haggling between the Malays and non-Malays was refuted by Adam (2004). According to Adam (2004), the truth is the Malays do not get any sort of compensations from the compromise. The special position of Malays is not a new provision in the British administration. This provision already existed in Treaty of the Federation 1948 under the authority of the High Commissioner. In Part III, Commanding Power of the Federation, Clause 19 (c) shall be the duty of the British High Commissioner to protect the safety of the special situation of the Malays. The Reid Commission was only to continue for 15 years after the independence. Harding (1996) who touched on Article 153 which is the special position of the Malays explained that it was something that was quite different in a constitution. The Federal Constitution does not protect minority rights but the rights of the majority. However, this question can exist in the framework of the Constitution of Malaysia and the concept of discrimination can be adapted to the concept of equality which is a basic concept in constitutional law.

Wan Mohd Nor also discusses this aspect by saying that this privilege is something that is fair to the Malays, for four reasons, namely to the role of giving character and personality, establishing an international civilization, defending this nation from external threats and occupation and to be indulgence and showing goodwill.

For Fernando (2002), the provisions of the special position of Malays created problems in the discussion in the Working Committee of the Alliance Party. This is because the Alliance requested that the special position is reviewed after 15 years but UMNO leaders did not agree because it will be disputed by the Malays. The study by Awang found that social contract mentioned is an important element in the history of the racial and nation building. Before the arrival of British colonial, Malaya originally identified with its core population of the Malays. When the colonists brought the Chinese and Indian in mass to become a workforce for the manipulation of its own colonial economy, the country's demographic situation is directly transformed. At the insistence of English, the Malays must accept the conditions of independence to be granted only if the families of the 
original immigrants are accepted as citizens. In return to the granting of citizenship status, the leaders of other communities then agreed to accept the provisions relating to the interests of the Malays. Matters forming the basis of the agreement are the position of the Malay Rulers, position of Islam as the federal religion, Malay language as the national and official language and the special position of the Malays and the Bumiputera. That's what called a social contract in the context of the establishment of this country after the being freed from the colonial shackles.

The study made by Rosfazila and Ayu Nor Azilah showed that the level of knowledge of the Malays of their special rights in the constitution is good $(97 \%)$ and the level of their understanding of the privilege is still low $(62.5 \%)$. Although, this research is quantitative but not comprehensive in nature due to small number of respondents and only consists of the Malays. It also tries to innovate the research on the constitution by using a questionnaire and it is a good start.

In the book entitled Ethnic Relations Module which was made a compulsory text for students in Public Higher Education Institutions, it also explained the provisions of the Islamic religion and Malay special position. The same method was also made by Mansor who also touched on the provisions of Islam and the special position of Malays. While discussion of the special position of Malays by looking at the rationale of the Malays getting this privileged position because this is an agreement between the Malays and the non-Malays in which the non-Malays obtained their citizenship via jus soli and the Malays get the special position, Malay language as the national language and Islam as a religion of the federation and based on statistics, it appears that the Malays have lagged far behind in the civil service, economic and education. This book concludes that respecting the rights and interests of all ethnic groups in Malaysia as enshrined in the constitution is to be appreciated together in order to avoid any conflicts that would arise. Based on previous studies, there are gaps that have not been studied on the perceptions of young people in particular to the provisions of the Malays which have always been a polemic and issues in pluralistic Malaysian society from the perspective of ethnic relations. This is because previous researches are qualitative in nature by referring to the current available documents.

Objective of the study: The objectives of this study are:

- To identify students' perceptions of the provisions of the Malays in the constitution
- To identify students' perceptions of the provisions of the Malays in the constitution according to demographics

\section{MATERIALS AND METHODS}

This study is a descriptive study about the perception among students in institutions. According to Wiersma (1995), this method is one of the best methods if the study is a study to measure or assess the attitudes, perceptions and performance of a program. Descriptive form is also used in line with the research needs which is to look at a phenomenon that is currently happening (Konting, 1990). Therefore, for that purpose, a set of questionnaire is designed and prepared by the researcher to achieve the objectives of the study. According to Tuckman (1999), the questionnaire is an effective way to obtain information from respondents.

Population for this study is all students in year three from four selected universities namely UM, USM, UKM and UPM. Financial and time constraints have prevented the researcher from conducting research in all Public Higher Education Institutions. The selection of student from UKM and UPM was done because they are exposed to ethnic diversity and all three universities are located in the Klang Valley and Klang Valley also reflects the population of Malaysia and the students consist of varied ethnic. Although, USM is not located in the Klang Valley, the university possesses the same features as UM, UKM and UPM and these four universities is among the first university that was established and classified as Research University. This gives an impact on the enhancement of student associations compared to new universities and has always been the preferred choice of students who chose to enter Public Higher Education Institutions. This situation is very significant and realistic to the student perception towards the issue, especially to something that involves issues of ethnic relations.

The sample was made by means of cluster sampling. Cluster sampling can be used by determining the number of such groups by state, district or county. The selection is appropriate if the population is large and scattered in uneven places. It can also save time and reduce various problems since the researcher classify samples in one batch before the random selection done. Thus, to determine the number of respondents, sample size determination table suggested by Krejcie and Morgan (1970) was used.

Based on student population in four IPTA as shown in Table 3, the sample size for this study was 800 . According to Noah (2002), the larger the sample size, the smaller the sampling error. To ensure that every 
Table 3: Number of 3rd year students in four IPTA for 2009/2010 session

\begin{tabular}{lc} 
IPTA & Number of 3rd year students \\
\hline UM & 2595 \\
USM & 3157 \\
UKM & 4814 \\
UPM & 3894 \\
Total & 14460 \\
\hline
\end{tabular}

Data from corresponding IPTA

community is represented then the random sampling strata was used in the ratio according to ethnic Malays, Chinese and Indians of 60:30:10 and a total of 800 students will be selected as respondents in this study based on sample size determination table by Krejcie and Morgan (1970). The instrument used for data collection in this study is a set of questionnaires. According to Oppenheim (2004) and Tuckman (1999), questionnaires and interviews are two forms of an effective instrument to obtain information from respondents apart from making observations. All questions are in positive form and respondents were required to state their perception according the Likert scale. The questionnaire consists of two parts namely Part A and B. Part A is related to the demographics of the respondents. Part $\mathrm{B}$ is related to the students' perception towards the provision of the Malays in the constitution.

In this study, the validity of the questionnaire is determined by a panel of experts. Four experts have reviewed which consists of two constitutional experts each a specialist in ethnic relations and the construction of a questionnaire. Reliability refers to the stability and consistency of the instrument in measuring a concept. A popular test which is frequently used in measuring the consistency of a concept is the Alpha Cronbach. The reliability of Cronbach Alpha value is between the values of 0.0-1.0. According to Konting (1990), Alpha value exceeding 0.60 is often used as an index of reliability in research. Therefore in this study, the researcher has set the Alpha value that exceeds 0.60 as a reliable value for all parts of the questionnaires being studied. Next to determine the reliability of the questionnaire which was prepared, the researcher has conducted a pilot study. The pilot study was carried out to identify weaknesses and strengths contained in the questionnaires prepared. Therefore, before the questionnaires are circulated, 50 students have been chosen to answer the questionnaires beforehand. Results obtained showed that all 50 students have no problem to understand the questions and did not ask what is required by the question. Afterwards using the SPSS program, the researcher computes the reliability and Alpha Cronbach values. It is found that the Alpha Cronbach value obtained for all items is $>0.6$. Therefore, the questionnaire developed for this study is suitable for use.
Data gathered was analyzed using Statistical Package for the Social Science (SPSS) Version 16 program via min, Standard Deviation, Chi-square and cross-tabulation. Descriptive statistics such as frequency, percentage, mean score or min, cross-table statistics (crosstabulation) and the correlation coefficient are used to describe the background of the respondent's and analyze students' perception of Malay students in the Federal Constitution.

\section{RESULTS AND DISCUSSION}

Background of respondents: Respondents of this study consist of 3rd year students at four universities namely UM, USM, UKM and UPM. A total of 800 students responded to questionnaires. The background of the respondents was asked in Part A of the questionnaire. Respondent's background discussion will be divided into three parts namely profiles, academic background and place of residence of the respondents. Table 4 shows the information about the respondents who participated in this study. From a total of 800 respondents, a total of 552 people (69\%) are female students while a total of 248 are male students $(31 \%)$. A majority of respondents which correspond to a total of 484 persons $(60.5 \%)$ were Malays followed by a total of 242 persons ( $30.3 \%$ ) Chinese while respondents from Indian ethnic were about 74 persons $(9.3 \%)$. This is in accordance to the ratio of respondent determination by ethnics which are the Malays 60 , Chinese $30 \%$ and Indian 10\% to reflect Malaysia's population statistics. The composition of respondents obtained also shows that a large number of respondents were Muslim or 485 persons $(60.6 \%$ ) followed by Buddhist of $187(23.4 \%)$. Meanwhile, there were 68 persons ( $8.5 \%)$ of respondents professing Hindu religion, 52 persons $(6.5 \%)$ are Christian and no religious group represented by 8 persons ( $1 \%)$.

Table 5 shows information on the background of the respondents which are related to the education stream. It was found that the majority of respondents which is 564 persons $(70.5 \%)$, enrolled in national schools at primary level and the majority or a total of 691 persons (86.4\%) then continued their studies at the national secondary schools across the country. In primary national-type schools, the number of 236 persons ( $29.5 \%$ ) was recorded and in secondary national-type schools consists of a total of 109 persons $(13.6 \%)$. Students' perception towards the Malays (Table 6), students accepted that the position of the Malays are better than non-Malays, privileges of the Malays have improved their standard of living, the use of quotas in government policy should be maintained. This is in accordance with the statement that students are still aware and sensitive and the government must take into 
account the privileges of the Malays in any policy that will be carried out. However, the students began to accept that as a pluralistic nation, the same treatment should be given to all races and the use of quotas in government policy must be extended to other races. Students began to accept that poor and qualified non-Malays should also be given assistance. This is consistent with the recommendations Huang-Thio (1964) who is in the opinion that Article 153 failed to achieve its objectives and suggested the government to emulate the Indian Constitution which is more neutral.

Research findings revealed that the use of quotas in government policy should be maintained and expanded and the perception has not changed since the study by Noor (2005) also obtained the same result, namely 43 and 10\% Malay students agreed compared to Chinese students (6 and 25\%) and Indian students (13 and 29\%). Similarly, there is also findings that revealed that only part of the Malays who benefit from the privileges of the Malays and it is the same with the opinion of S.M.

\begin{tabular}{lcc} 
Table 4: Respondent profiles & & \\
\hline Profile $(\mathrm{n}=800)$ & Number & Percentage \\
\hline Sex & 248 & 31.0 \\
Male & 552 & 69.0 \\
Female & & \\
Race & 484 & 60.5 \\
Malay & 242 & 30.3 \\
Chinese & 74 & 9.30 \\
Indian & & \\
Religion & 485 & 60.6 \\
Islam & 187 & 23.4 \\
Buddha & 68 & 8.50 \\
Hindu & 52 & 6.50 \\
Christian & 8 & 1.00 \\
No religion & &
\end{tabular}

Table 5: Respondents' academic background

\begin{tabular}{lcc}
\hline Academic background $(n=800)$ & Number & Percentage \\
\hline Primary school stream & & \\
National & 564 & 70.5 \\
National type & 236 & 29.5 \\
Secondary school stream & & \\
National & 691 & 86.4 \\
National type & 109 & 13.6 \\
\hline
\end{tabular}

Huang-Thio that Article 153 is a provision that was not enough and not very profitable to the majority of the Malay population. Instead, the impacts of these provisions only benefit the Malays who are already rich. This right only benefits the Malays from the middle class only and it does not reach the general mass of the Malays especially those living in rural areas which form the largest number of Malay population (Huang-Thio, 1964). For the statement that use of quotas should be limited in terms of its time of implementation, restricted based on the requirements, privileges of the Malays have improved the standard of living of the Malays clearly shows that students still wanted to accept and maintain provisions concerning the Malays in the constitution.

Students' perception towards the malays in the constitution following the ethnic, religion, university entrance approval, primary school education streaming and secondary school education streaming: Table 7 shows students' perception towards the Malay provision in a way that the status of the Malays is better than the non-Malays in the constitution. The cross-ethnic survey discovers that the majority of Malay students $(80.2 \%)$ agreed, the Chinese (69\%) and Indians (62.1\%) also agreed to the statement and the same pattern was observed following religion. However, there is not any significant difference that can be seen in other demographic factors.

It is found from Table 8 that the students' agreement towards the statement about the same treatment that is ought to be given to all ethnics in Malaysia is in variation: the Malay students $(67.4 \%)$, Chinese $(87.1 \%)$ and Indian $(85.1 \%)$ and the same pattern following religion. Yet, there is no significant difference for other demographic factors except for the university entrance approval for diploma holders $(59.8 \%)$. For the statement in Table 9 that is the use of quota in the country's development policy and programme must be maintained, there is a significant difference by ethnic (Malay $87.4 \%$, Chinese $20.6 \%$ and

Table 6: Students perceptions towards malay provision

\begin{tabular}{|c|c|c|c|}
\hline \multirow[b]{2}{*}{ Items } & \multicolumn{3}{|c|}{ Moderately } \\
\hline & Do not agree & agree & Agree \\
\hline Positions of the Malays are better than the non-Malays in the constitution & $59(7.40)$ & $140(17.5)$ & $601(75.2)$ \\
\hline The same treatment is given to all ethnic groups in Malaysia & $64(8.00)$ & $134(16.8)$ & $602(75.2)$ \\
\hline The use of quotas in national policies and development programs must be maintained & $155(19.40)$ & $150(38.1)$ & $495(61.9)$ \\
\hline Time of implementation and the use of quotas in national policies and development programs should be limited & $131(16.40)$ & $235(29.4)$ & $434(54.2)$ \\
\hline The use of quotas in national policies and development programs should be limited based on need & $109(13.60)$ & $166(20.8)$ & $525(65.7)$ \\
\hline The use of quotas in national policies and development programs should be set aside in the implementation stage & $185(23.10)$ & $289(36.1)$ & $326(40.7)$ \\
\hline The use of quotas in national policies and development programs should be expanded to other communities & $142(17.18)$ & $190(23.8)$ & $468(58.5)$ \\
\hline The special position of Malays detriments racial unity & $306(38.30)$ & 175 (21.9) & $319(39.8)$ \\
\hline Privileges of the Malays have improved the position of the Malays compared to the non-Malays & $81(10.10)$ & $158(19.8)$ & $561(70.1)$ \\
\hline Only part of the Malays who receive benefits from the special position of Malays & $163(20.40)$ & $203(25.4)$ & $434(54.2)$ \\
\hline I do not care if the privileges of the Malays is not adopted in government policies & $360(45.00)$ & $181(22.6)$ & $259(32.4)$ \\
\hline
\end{tabular}


Res. J. Applied Sci., 7 (3): 165-176, 2012

Table 7: Students' perceptions towards the Malay provisions in the constitution following demographic factors

\begin{tabular}{lrrr}
\hline Parameters & Disagree & Less agree & Agree \\
\hline Ethnic & $18(3.7)$ & $78(16.1)$ & $388(80.2)$ \\
Malay & $27(11.2)$ & $48(19.8)$ & $167(69.0)$ \\
Chinese & $14(18.9)$ & $14(18.9)$ & $46(62.1)$ \\
Indian & & & \\
Religion & $18(3.7)$ & $78(16.1)$ & $389(80.2)$ \\
Islam & $19(10.1)$ & $37(19.8)$ & $131(70.0)$ \\
Buddha & $14(20.6)$ & $14(20.6)$ & $40(58.8)$ \\
Hindu & $6(11.6)$ & $10(19.2)$ & $36(69.2)$ \\
Christian & $2(25.0)$ & $1(12.5)$ & $5(62.5)$ \\
No religion & & & \\
University entrance approval & $4(5.2)$ & $12(15.6)$ & $61(79.2)$ \\
Diploma & $21(7.7)$ & $53(19.8)$ & $201(73.0)$ \\
Matriculation & $33(7.7)$ & $71(16.5)$ & $326(75.9)$ \\
STPM & $1(5.6)$ & $4(22.2)$ & $13(72.2)$ \\
Others & & & \\
Primary education streaming & $29(5.2)$ & $92(16.3)$ & $443(78.5)$ \\
National schools & $30(12.7)$ & $48(20.3)$ & $158(66.9)$ \\
National type schools & & \\
Secondary education streaming & $51(7.4)$ & $120(13.4)$ & $520(75.2)$ \\
Secondary schools & $8(7.4)$ & $20(18.2)$ & $81(74.3)$ \\
Secondary type schools & \multicolumn{3}{l}{} \\
The Malay position is better in comparison with that of the non-Malays \\
the constitution
\end{tabular}

Table 8: Students' perception towards the Malay provision in the constitution following the demographic factors

\begin{tabular}{lrrr}
\hline Parameters & Disagree & Less agree & Agree \\
Ethnic & & & \\
Malay & $55(11.4)$ & $103(21.3)$ & $326(67.4)$ \\
Chinese & $6(2.5)$ & $23(6.5)$ & $213(87.1)$ \\
Indian & $3(4.1)$ & $8(10.8)$ & $63(85.1)$ \\
Religion & & & \\
Islam & $54(11.4)$ & $103(21.2)$ & $327(67.4)$ \\
Buddha & $5(2.6)$ & $18(9.6)$ & $164(87.7)$ \\
Hindu & $3(4.4)$ & $8(11.8)$ & $57(83.8)$ \\
Christian & $0(0.0)$ & $3(5.8)$ & $49(94.2)$ \\
No religion & $1(12.5)$ & $2(25.0)$ & $5(62.5)$ \\
University entrance approval & & & \\
Diploma & $12(15.6)$ & $19(24.7)$ & $46(59.8)$ \\
Matriculation & $26(9.5)$ & $52(18.9)$ & $197(71.6)$ \\
STPM & $24(5.6)$ & $61(14.2)$ & $345(80.2)$ \\
Others & $2(11.1)$ & $2(11.1)$ & $14(77.8)$ \\
Primary education streaming & & & \\
National schools & $56(10.2)$ & $106(18.8)$ & $400(70.9)$ \\
National type schools & $6(2.5)$ & $28(11.9)$ & $202(85.6)$ \\
Secondary education streaming & & & \\
National secondary schools & $58(8.4)$ & $119(19.2)$ & $298(74.4)$ \\
National type secondary schools & $6(5.5)$ & $15(13.8)$ & $88(80.7)$ \\
Current residence & & & \\
University hostel & $51(8.6)$ & $105(17.7)$ & $437(73.7)$ \\
Rented house & $11(7.0)$ & $24(15.2)$ & $123(77.8)$ \\
Parents' house & $2(4.0)$ & $5(10.20)$ & $42(85.70)$ \\
\hline
\end{tabular}

The same treatment should be given to all ethnic groups in Malaysia

Indian $29.8 \%$ ), religion, primary and secondary education streaming. However, there has been no difference for the university entrance approval factor.

For Table 10, students' perception towards the statement of the use of quota in the country's policy and development programme should have its time of implementation limited is shown to have no difference following the demographic factors that demonstrates students' agreement with the particular statement. The
Table 9: Students' perception towards the Malay provisions in the constitution by demographic factors

\begin{tabular}{lrrr}
\hline Factors & Disagree & Less agree & \multicolumn{1}{c}{ Agree } \\
Ethnic & & & \\
Malay & $14(2.9)$ & $47(9.7)$ & $423(87.4)$ \\
Chinese & $103(42.6)$ & $89(36.8)$ & $50(20.6)$ \\
Indian & $38(51.3)$ & $14(18.9)$ & $22(29.8)$ \\
Religion & & & \\
Islam & $14(2.9)$ & $47(9.7)$ & $424(87.4)$ \\
Buddha & $78(41.7)$ & $73(39.0)$ & $36(19.2)$ \\
Hindu & $34(50.0)$ & $12(17.6)$ & $22(32.4)$ \\
Christian & $25(48.1)$ & $16(30.8)$ & $11(21.1)$ \\
No religion & $4(50.0)$ & $2(25.0)$ & $25(25.0)$ \\
University entrance approval & & & \\
Diploma & $4(5.2)$ & $6(7.8)$ & $67(87.1)$ \\
Matriculation & $30(11.0)$ & $49(17.8)$ & $106(71.3)$ \\
STPM & $120(27.9)$ & $92(21.4)$ & $218(50.7)$ \\
Others & $1(5.6)$ & $3(16.7)$ & $14(77.8)$ \\
Primary education streaming & & & \\
National schools & $56(9.9)$ & $69(12.2)$ & $439(77.8)$ \\
National type schools. & $99(41.9)$ & $81(84.3)$ & $56(23.7)$ \\
Secondary education streaming & & & \\
National secondary education & $120(17.4)$ & $121(17.5)$ & $450(65.2)$ \\
National type secondary education & $35(32.1)$ & $29(26.6)$ & $45(41.3)$ \\
Current residence & & & \\
University hostel & $104(17.6)$ & $107(18.0)$ & $382(64.4)$ \\
Rented house & $32(20.2)$ & $73(70.9)$ & $93(58.8)$ \\
Parents' house & $19(38.8)$ & $10(20.4)$ & $20(40.8)$ \\
\hline
\end{tabular}

The use of quota in the country's policy and development programme must be maintained

Table 10: Students' perception towards the Malay provisions in the constitution following the demographic factors

\begin{tabular}{lrrr}
\hline Factors & Disagree & Less agree & Agree \\
\hline Ethnic & & & \\
Malay & $60(12.4)$ & $107(22.1)$ & $279(57.7)$ \\
Chinese & $41(16.9)$ & $43(17.8)$ & $121(50.0)$ \\
Indian & $30(40.6)$ & $16(21.6)$ & $34(45.4)$ \\
Religion & & & \\
Islam & $40(12.4)$ & $146(30.1)$ & $279(67.6)$ \\
Buddha & $27(14.4)$ & $64(34.2)$ & $96(51.4)$ \\
Hindu & $28(40.2)$ & $8(11.8)$ & $32(47.1)$ \\
Christian & $15(28.8)$ & $14(26.9)$ & $23(44.3)$ \\
No religion & $1(12.5)$ & $3(37.5)$ & $4(50.0)$ \\
University entrance approval & & & \\
Diploma & $7(9.1)$ & $30(39.0)$ & $40(52.0)$ \\
Matriculation & $46(16.7)$ & $80(29.1)$ & $149(54.1)$ \\
STPM & $77(17.9)$ & $122(28.4)$ & $231(63.8)$ \\
Others & $1(5.6)$ & $3(16.7)$ & $14(77.8)$ \\
Secondary education streaming & & & \\
National secondary education & $86(15.3)$ & $165(29.3)$ & $313(55.4)$ \\
National type secondary education & $45(19.0)$ & $70(29.7)$ & $121(51.2)$ \\
Current residence & & & \\
University hostel & $118(17.0)$ & $204(29.5)$ & $369(53.4)$ \\
Rented house & $13(12.0)$ & $31(28.4)$ & $65(59.6)$ \\
\hline
\end{tabular}

The use of quota in the country's policy and development programme should have its time of implementation limited

abovementioned result concerning the students' perception (with no significant difference) is observed to be similar with the result shown in Table 11 which concerns with the statement the use of quota in the national policy and development programme should be restricted based on specific needs. Table 12 has shown students' perception towards the Malay provisions which is the use of quota in the national policy and development 
Res. J. Applied Sci., 7 (3): 165-176, 2012

Table 11: Students' perception towards the Malay provisions in the constitution following the demographic factors

\begin{tabular}{|c|c|c|c|}
\hline Factors & Disagree & Less agree & Agree \\
\hline \multicolumn{4}{|l|}{ Ethnic } \\
\hline Malay & $50(10.4)$ & $107(22.1)$ & $327(67.6)$ \\
\hline Chinese & $33(13.6)$ & $43(17.8)$ & $166(68.6)$ \\
\hline Indian & $26(35.1)$ & $16(21.6)$ & $32(43.2)$ \\
\hline Religion & $13(26.0)$ & $9(17.3)$ & $30(57.7)$ \\
\hline Islam & $1(12.5)$ & $3(37.5)$ & $4(50.0)$ \\
\hline \multicolumn{4}{|l|}{ Buddha } \\
\hline Hindu & $7(9.1)$ & $18(23.4)$ & $52(67.7)$ \\
\hline Christian & $49(14.1)$ & $61(22.2)$ & $175(63.7)$ \\
\hline No religion & $62(14.4)$ & $85(19.8)$ & $283(65.8)$ \\
\hline University entrance approval & $1(5.6)$ & $2(11.1)$ & $15(83.3)$ \\
\hline \multicolumn{4}{|l|}{ Diploma } \\
\hline Matriculation & $71(12.6)$ & $126(22.3)$ & $367(65.0)$ \\
\hline STPM & $38(16.1)$ & $40(16.9)$ & $122(66.9)$ \\
\hline \multicolumn{4}{|l|}{ Others } \\
\hline Secondary education streaming & $100(14.5)$ & $152(22.0)$ & $439(63.7)$ \\
\hline National secondary education & $9(8.3)$ & $14(12.8)$ & $86(78.9)$ \\
\hline \multicolumn{4}{|c|}{$\begin{array}{l}\text { The use of quota in the national policy and development programme should } \\
\text { be restricted based on specific needs }\end{array}$} \\
\hline \multicolumn{4}{|c|}{$\begin{array}{l}\text { Table 12: Students' perception towards the Malay provisions in the } \\
\text { constitution following the demographic factors }\end{array}$} \\
\hline Factors & Disagree & Less agree & Agree \\
\hline \multicolumn{4}{|l|}{ Ethnic } \\
\hline Malay & $114(23.6)$ & $176(36.4)$ & $194(40.1)$ \\
\hline Chinese & $43(17.8)$ & $101(41.7)$ & $98(50.5)$ \\
\hline Indian & $28(37.8)$ & $12(16.2)$ & $34(45.9)$ \\
\hline \multicolumn{4}{|l|}{ Religion } \\
\hline Islam & $104(23.6)$ & $177(36.5)$ & $194(40.0)$ \\
\hline Buddha & $30(16.1)$ & $79(42.2)$ & $78(41.7)$ \\
\hline Hindu & $26(38.3)$ & $10(14.7)$ & $32(47.1)$ \\
\hline Christian & $14(26.9)$ & $18(34.6)$ & $20(38.5)$ \\
\hline No religion & $1(12.5)$ & $5(62.5)$ & $2(25.0)$ \\
\hline \multicolumn{4}{|l|}{ University entrance approval } \\
\hline Diploma & $20(26.0)$ & $29(37.7)$ & $28(36.4)$ \\
\hline Matriculation & $68(24.7)$ & $98(35.6)$ & $109(39.6)$ \\
\hline STPM & $95(22.1)$ & $154(35.8)$ & $181(42.1)$ \\
\hline Others & $2(11.2)$ & $8(44.4)$ & $8(44.4)$ \\
\hline \multicolumn{4}{|l|}{ Primary education streaming } \\
\hline National schools & $134(23.8)$ & $198(35.1)$ & $178(41.2)$ \\
\hline National type schools & $51(21.6)$ & $91(38.6)$ & $94(39.8)$ \\
\hline \multicolumn{4}{|l|}{ Secondary education streaming } \\
\hline National secondary schools & $171(24.7)$ & $247(35.7)$ & $273(39.5)$ \\
\hline National secondary type schools & $14(12.9)$ & $42(38.5)$ & $53(48.6)$ \\
\hline
\end{tabular}

programme must be cast aside at the implementation level has shown a difference by ethnic but has not shown any significant difference for other demographic factors. Table 13 has shown that students' perception towards the Malay provisions which is the use of quota in national policies and development programmes must be extended to other races. The cross-cultural survey has found that a majority of Malay students $(55.8 \%)$ did not agree and showed less agreement if compared to Chinese (17.8\%) and Indian (25.7\%) students towards the statement and the same pattern has been seen following religion and primary and secondary education streaming. However, no significant difference has been observed following other demographic factors.
Table 13: Students' perception towards the Malay provision in the constitution following the demographic factors

\begin{tabular}{lrrr}
\hline Factors & Disagree & Less agree & \multicolumn{1}{c}{ Agree } \\
\hline Ethnic & & & \\
Malay & $117(24.2)$ & $153(31.6)$ & $214(43.9)$ \\
Chinese & $14(5.8)$ & $29(12.0)$ & $199(82.3)$ \\
Indian & $11(14.9)$ & $8(10.8)$ & $55(74.3)$ \\
Religion & & & \\
Islam & $117(24.2)$ & $154(31.8)$ & $214(44.1)$ \\
Buddha & $12(6.4)$ & $21(11.2)$ & $154(82.3)$ \\
Hindu & $10(14.7)$ & $7(10.3)$ & $51(75.0)$ \\
Christian & $3(5.8)$ & $7(13.5)$ & $32(80.3)$ \\
No religion & $0(0.0)$ & $1(12.5)$ & $7(87.5)$ \\
University entrance approval & & & \\
Diploma & $21(27.3)$ & $19(24.7)$ & $37(48.1)$ \\
Matriculation & $56(20.4)$ & $80(29.1)$ & $139(50.5)$ \\
STPM & $61(14.1)$ & $86(20.0)$ & $283(65.9)$ \\
Others & $4(22.3)$ & $5(27.8)$ & $9(50.0)$ \\
Primary education streaming & & & \\
National schools & $125(22.2)$ & $162(28.7)$ & $277(49.1)$ \\
National type schools. & $17(7.2)$ & $28(11.9)$ & $191(81.0)$ \\
Secondary education streaming & & & \\
National secondary schools & $134(19.4)$ & $174(25.2)$ & $383(55.4)$ \\
National type secondary schools & $8(7.4)$ & $16(14.7)$ & $85(78.0)$ \\
\hline
\end{tabular}
The use of quota in national policies and development programmes must be extended to other races

Table 14: Students' perception towards the Malay provision in the constitution following the demographic factors

\begin{tabular}{lrrr}
\hline Factors & Disagree & Less agree & Agree \\
\hline Ethnic & & & \\
Malay & $270(55.8)$ & $108(22.3)$ & $106(21.9)$ \\
Chinese & $25(10.4)$ & $52(21.5)$ & $165(68.2)$ \\
Indian & $11(14.9)$ & $15(20.3)$ & $48(64.9)$ \\
Religion & & & \\
Islam & $271(55.9)$ & $108(22.3)$ & $106(21.8)$ \\
Buddha & $19(10.1)$ & $39(20.9)$ & $129(68.9)$ \\
Hindu & $11(16.2)$ & $13(19.1)$ & $44(64.7)$ \\
Christian & $5(9.6)$ & $15(28.8)$ & $32(61.5)$ \\
No religion & $0(0.0)$ & $0(0.0)$ & $8(100.0)$ \\
University entrance appr oval & & & \\
Diploma & $40(52.0)$ & $14(18.2)$ & $23(29.2)$ \\
Matriculation & $125(45.4)$ & $68(24.7)$ & $82(29.8)$ \\
STPM & $135(31.4)$ & $86(20.0)$ & $209(48.6)$ \\
Others & $6(33.3)$ & $7(38.6)$ & $5(27.8)$ \\
Primary education streaming & & & \\
National schools & $280(49.7)$ & $130(23.0)$ & $154(27.3)$ \\
National type schools & $26(11.1)$ & $45(19.1)$ & $165(69.9)$ \\
Secondary education streaming & & & \\
National secondary schools & $285(41.3)$ & $155(22.4)$ & $251(36.3)$ \\
National type secondary schools & $21(19.2)$ & $20(18.3)$ & $68(62.4)$ \\
\hline The special position of the Malays has affected racial unity & \\
& & & \\
& &
\end{tabular}

Table 14 shows students' perception towards the Malay provisions according to demographic factors as stated whereby the special position of the Malays has affected racial unity.

The cross-ethnic survey learns that the majority of the Malay students $(78.1 \%)$ had expressed their disagreement and lack of agreement in comparison to their Chinese and Indian counterparts (31.9 and 25.2\%, respectively) and the same pattern had been established following factors of religion, primary and secondary school streaming. Yet, no significant difference has been seen for other demographic factors. 
Res. J. Applied Sci., 7 (3): 165-176, 2012

Table 15: Students' perception towards the Malay provision in the constitution following the demographic factors

\begin{tabular}{|c|c|c|c|}
\hline Factors & Disagree & Less agree & Agree \\
\hline \multicolumn{4}{|l|}{ Ethnic } \\
\hline Malay & $23(6.8)$ & $98(20.2)$ & $353(73.0)$ \\
\hline Chinese & $35(14.4)$ & $48(16.8)$ & $152(68.8)$ \\
\hline Indian & $13(17.6)$ & $12(16.2)$ & $49(66.2)$ \\
\hline \multicolumn{4}{|l|}{ Religion } \\
\hline Islam & $33(6.8)$ & $98(20.2)$ & $354(73.0)$ \\
\hline Buddha & $29(15.5)$ & $39(20.9)$ & $119(63.7)$ \\
\hline Hindu & $12(17.7)$ & $11(16.2)$ & $45(66.2)$ \\
\hline Christian & $6(11.5)$ & $9(17.3)$ & $37(71.2)$ \\
\hline No religion & $1(12.5)$ & $1(12.5)$ & $6(75.0)$ \\
\hline \multicolumn{4}{|l|}{ University entrance approva } \\
\hline Diploma & $6(7.8)$ & $14(18.2)$ & $57(74.0)$ \\
\hline Matriculation & $28(10.2)$ & $56(20.4)$ & $191(69.5)$ \\
\hline STPM & $46(10.7)$ & $81(18.8)$ & $303(70.4)$ \\
\hline Others & $1(5.6)$ & $7(38.9)$ & $10(56.6)$ \\
\hline \multicolumn{4}{|l|}{ Primary education streaming } \\
\hline National schools & $47(8.4)$ & $110(19.5)$ & $407(72.2)$ \\
\hline National type schools & $34(14.4)$ & $48(20.3)$ & $154(65.3)$ \\
\hline \multicolumn{4}{|l|}{ Secondary education streaming } \\
\hline National secondary schools & $70(10.2)$ & $135(19.5)$ & $486(70.3)$ \\
\hline National type secondary schools & $11(12.1)$ & $23(21.1)$ & $68(62.4)$ \\
\hline \multicolumn{4}{|c|}{$\begin{array}{l}\text { The special position of the Malays has improved their position as compared } \\
\text { to the non-Malays' }\end{array}$} \\
\hline \multicolumn{4}{|c|}{$\begin{array}{l}\text { Table 16: Students' perception towards the Malay provision in the } \\
\text { constitution following the demographic factors }\end{array}$} \\
\hline Factors & Disagree & Less agree & Agree \\
\hline \multicolumn{4}{|l|}{ Ethnic } \\
\hline Malay & $57(11.8)$ & $107(22.1)$ & $320(66.2)$ \\
\hline Chir & $79(32.7)$ & $81(33.7)$ & $82(33.9)$ \\
\hline Indian & $27(36.5)$ & $15(20.3)$ & $32(43.2)$ \\
\hline \multicolumn{4}{|l|}{ Religion } \\
\hline Islam & $57(11.8)$ & $107(22.1)$ & $321(66.2)$ \\
\hline Buddha & $63(33.7)$ & $57(30.5)$ & $67(35.8)$ \\
\hline Hindu & $26(38.2)$ & $14(26.0)$ & $28(41.2)$ \\
\hline Christian & $16(30.8)$ & $20(38.5)$ & $16(30.7)$ \\
\hline No religion & $1(12.5)$ & $5(62.5)$ & $2(25.0)$ \\
\hline \multicolumn{4}{|l|}{ University entrance approval } \\
\hline Diploma & $10(13.0)$ & $20(26.0)$ & $47(61.1)$ \\
\hline Matriculation & $44(17.4)$ & $73(26.3)$ & $154(56.0)$ \\
\hline STPM & $102(23.7)$ & $106(24.7)$ & $22(51.6)$ \\
\hline Others & $3(16.6)$ & $4(22.2)$ & $11(61.1)$ \\
\hline \multicolumn{4}{|l|}{ Primary education streaming } \\
\hline National schools & $84(14.8)$ & $129(22.9)$ & $351(62.3)$ \\
\hline National type schools & $79(33.5)$ & $74(31.4)$ & $83(35.2)$ \\
\hline \multicolumn{4}{|l|}{ Secondary education streaming } \\
\hline National secondary schools & $129(18.7)$ & $180(26.0)$ & $382(55.3)$ \\
\hline National type secondary schools & $34(31.1)$ & $23(21.1)$ & $52(49.7)$ \\
\hline
\end{tabular}

Only a portion of the Malays have benefited from the special status

Table 15 shows the students' perception towards the Malay provisions following demographic factors as stated in that the special position of the Malays has improved their position as compared to the non-Malays. There is no significant difference that explains that all students are in unison with the statement. Table 16 has shown the students' perception towards the Malay provision following the demographic factors as stated which is only a portion of the Malays have benefited from the special status. The survey has come to the conclusion that there is a variation of agreement between the Malay students $(66.2 \%)$, Chinese $(33.9 \%)$ and Indian $(43.2 \%)$ and the same
Table 17: Students' perception towards the Malay provision in the constitution following the demographic factors

\begin{tabular}{lrrr}
\hline Factors & Disagree & Less agree & Agree \\
\hline Ethnic & & & \\
Malay & $306(63.2)$ & $86(17.8)$ & $92(19.0)$ \\
Chinese & $42(17.4)$ & $72(29.8)$ & $128(52.9)$ \\
Indian & $12(16.2)$ & $23(31.1)$ & $39(52.7)$ \\
Religion & & & \\
Islam & $307(63.3)$ & $86(17.7)$ & $92(19.0)$ \\
Buddha & $30(16.1)$ & $55(29.4)$ & $102(54.6)$ \\
Hindu & $12(17.7)$ & $22(32.4)$ & $34(50.0)$ \\
Christian & $9(17.3)$ & $15(28.8)$ & $28(53.9)$ \\
No religion & $2(25.0)$ & $3(37.5)$ & $3(35.5)$ \\
University entrance appr oval & & & \\
Diploma & $47(61.1)$ & $11(14.3)$ & $19(24.7)$ \\
Matriculation & $150(54.5)$ & $62(25.2)$ & $63(22.9)$ \\
STPM & $157(26.5)$ & $104(24.2)$ & $169(39.3)$ \\
Others & $6(33.3)$ & $4(22.2)$ & $8(44.4)$ \\
Primary education streaming & & & \\
National schools & $111(66.9)$ & $105(18.6)$ & $138(24.5)$ \\
National type schools & $39(16.5)$ & $76(32.2)$ & $34(51.3)$ \\
Secondary education streaming & & & \\
National secondary schools & $327(47.3)$ & $149(21.6)$ & $215(31.1)$ \\
National type secondary schools & $303(30.2)$ & $32(29.4)$ & $44(40.4)$ \\
\hline
\end{tabular}

pattern according to religion, primary and secondary education streaming. However, there has been no difference in terms of the university entrance approval.

Table 17 keeps an account of students' perception towards the Malay provisions following demographic factors as stated: I do not mind if the Malays special rights are not applied in government policies'. Based on the ethnic groups students' level of agreement whereby the Malay students $(19 \%)$ had given their agreement followed by the Chinese (52.9\%) and Indians (52.7\%) and the same pattern applies for religion also primary and secondary education streaming. However, no significant difference is noted according to the university entrance approval.

\section{CONCLUSION}

The analysis of perception as a whole towards the special provision for the Malays has shown that students have come to accept that the position of the Malays has been better than that of the non-Malays that the special rights have elevated their life status and that the use of quota in government policies needs to be maintained. This is in tandem with the statement that students need to be alert and sensitive where the government needs to consider the Malay's exclusive rights in any policies that are to be implemented. However, students have begun to process that as a multi-racial country, equal treatment should be given to all races and the use of quota in government policies need to be extended to other races as well. The study findings also show that although, the Malay students have faced the reality where Malaysia is a nation with various races they still wish to retain the 
status quo related to the provisions for Malay and Islam in the constitution. The analysis of perception according to demographic factors also finds some similarities and differences especially based on ethnic, religion, primary and secondary education streaming. The differences by the demographic factors are seen in matters like the status of the Malays is better than that of the other races, equal treatment needs to be given to all ethnic groups, the need to maintain the use of quota in the government policy, the use of quota in the government policy should be extended to other races, the special rights of the Malays has affected racial unity, only a portion of the Malays have benefited from the special rights and I do not mind if the Malays' exclusive provisions are not adopted in the government policies.

The similarities are apparent in statements like the use of quota should have its time of implementation restricted that the quota should be limited based on the needs and specialty of the Malays and that it has improved the life status of the Malays without any significant differences following the demographic factors. It has clearly demonstrated that the Malays still accept and wish to retain the provisions exclusive for the Malays, just like they accept and wish that the provisions for Islam are preserved in the constitution as opposed to the acceptance of their non-Malay counterparts. However, the Malay students are more open to accepting the limited implementation time for the use of quota in the government policy and that the quota should be restricted based on specific needs.

The study findings have been able to show that factors of ethnicity, religion, primary and secondary education streaming really influence students' perception towards Islam and the Malays in the constitution. This is at par with studies by Kamis (1994), Hassan (2004), Idris (2008), Muslim (2011) and Noor (2005). Therefore, these factors are really significant in fabricating the ethnic relations in Malaysia as it can ignite the sense of orientation, values, attitude and cultural sociology in an ethnic group. Significant differences from these factors are those that have made ethnic relations on campus one agenda that should be given the priority they deserve.

\section{REFERENCES}

Abas, M.S., 1985. Elements of Tradition in the Constitution of Malaysia. Dewan Bahasa dan Pustaka, Kuala Lumpur, Malaysia.

Adam, R., 2004. Political biography of Tunku Abdul Rahman Putra. Dewan Bahasa dan Pustaka, Kuala Lumpur, Malaysia.
Ali, S.H., 2008. The Malays: Their Problem and Future. The Others Press, Petaling Jaya.

Bakar, O., 2009. The Concept of Civilization Malaysia: Unity in Diversity. In: Consensus and Pluralism: Core Civilization Malaysia, Abdullah, H.I.R. (Ed.). Akademi Pengajian Melayu dan Pusat Dialog Peradaban, Universiti of Malaya, Kuala Lumpur, Mlaysia.

Bari, A.A., 2000. Filling and appreciation of independence: A study of law. Proceedings of the Seminar and Strengthening the Independence of Malaysia, September 11-13, 2000, Kuala Lumpur, Malaysia.

Bari, A.A., 2001. Constitution of Malaysia: The Foundations and Problems. Dewan Bahasa dan Pustaka, Kuala Lumpur, Malaysia.

Bari, A.A., 2005. Islam Dalam Perlembagaan Malaysia. Intel Multimedia and Publication, Malaysia.

Fernando, J.M., 2002. The Making of the Malayan Constitution. JMBRAS, Kuala Lumpur.

Harding, A., 1996. Law, Government and the Constitution in Malaysia. Malayan Law Journal Sdn. Bhd., Kuala Lumpur.

Hashim, M.S., 1987. Introduction the Constitution of Malaysia. Dewan Bahasa dan Pustaka, Kuala Lumpur, Malaysia.

Hashim, M.S., H.P. Lee and F.A Trindade, 1983. Constitution of Malaysia: Its Development, 19571977. Penerbit Fajar Bakti, Petaling Jaya, Malaysia.

Hassan, A.A., 2005. Solving Conflicts in a Multicultural Society: The Case of Kampung Medan. In: Reading on Ethnic Relations in a Multicultural Society, Hassan, M.K.K.Z. (Ed.). Penerbit UPM, Serdang, Malaysia.

Hassan, A.D., 2004. Ethnic relations in higher education: An ethnographic study and cultural models among students of different ethnic. Ph.D. Thesis, Faculty of Education, Universiti Kebangsaan Malaysia, Malaysia.

Hickling, R.H., 1960. An Introduction to the Federal Constitution. Government Printer, Kuala Lumpur.

Huang-Thio, S.M., 1964. Constitutional discrimination under the Malaysian constitution. Malaya Law Rev., 6: $1-6$.

Idris, F., 2008. The influence of individual attributes on inter-ethnic tolerance among early youth in Selangor. Ph.D. Thesis, University Putra Malaysia.

Jalil, F., 2007. Constitution Deal with Current Challenges and Future. In: Laws of Malaysia: 50 Years Across the Ages, Jalil, F. (Ed.). Fakulti Undang-Undang UKM, Bangi, Malaysia.

Kamis, A., 1994. A study of social background and their relationship with prejudice or tolerance attitude towards national integration. Ph.D. Thesis, Faculty of Science Social, Universiti Kebangsaan Malaysia, Malaysia. 
Khoon, H.P., 1988. Chinese Politics in Malaysia. Oxford University Press, Singapore.

Konting, M.M., 1990. Research Methods in Education. Dewan Bahasa dan Pustaka, Kuala Lumpur, Malaysia.

Krejcie, R.V. and D.W. Morgan, 1970. Determining sample size for research activities. Educ. Psychol. Measur., 30: $607-610$.

Means, G.P., 1991. Malaysian Politics: The Second Generation. Oxford University Press, Singapore.

Milne, R.S. and D.K. dan Mauzy, 1992. Politics and Government in Malaysia. Time Book International, Singapore.

Muslim, N., 2011. Islam and the Malays according to the constitution in the context of ethnic relations: Investigation on students in public higher education institutions. Ph.D. Thesis, Universiti of Malaya (UM), Malaysia.

Noah, S.M., 2002. Research Design: Philosophy, Theory and Practice. Penerbit UPM, Serdang, Malaysia.
Noor, M.M., 2005. Ethnic integration in IPTA. Institut Penyelidikan Pendidikan Tinggi Negara, Pulau Pinang, Malaysia.

Oppenheim, A.N., 2004. Questionnaire Design, Interviewing and Attitude Measurement. Heinemann, London.

Ratnam, K.J., 1969. Communalism and the Political Process in Malaya. University of Malaya Press, Kuala Lumpur.

Sani, H.Y.A., 1973. Our Constitution. Malaysian Law Publishers, Kuala Lumpur, Malaysia.

Sheriden, L.A and H.E. Groves, 1979. The Constitutions of Malaysia. Malayan Law Journal, Singapore.

Tuckman, B.W., 1999. Conducting Educational Research. Harcourt Brace College Publishers, Fort Worth.

Von Vorys, K., 1975. Democracy Without Consensus. Princeton University Press, Princeton.

Wiersma, W., 1995. Research Methods in Education: An Introduction. Allyn and Bacon, Boston, MA., USA. 